\title{
A tribute to E. Donnall Thomas
}

$T_{1}$ he bone marrow transplantation community mourns the death of its undisputed leader, Nobel laureate E. Donnall Thomas, who passed away October 20, 2012, at the age of 92 (Figure 1).

Don was born March 15, 1920, in Mart, a small town in rural Texas. His father, Edward E. Thomas, was a general practitioner, and his mother, Angie Hill Donnall, was a teacher. In his Nobel acceptance speech, Don described himself as a mediocre student in high school and during his first year at the University of Texas in Austin in 1937. To support himself during his undergraduate studies, Don worked various jobs; he met his future wife, Dorothy ("Dottie") Martin, during a snowball fight after waiting tables in her dormitory. They married in 1942 and had an exceptional life together in a partnership that included a dynamic loving family life with three children and grandchildren, as well as his research family. Dottie worked as a lab technician, administrator, and editor in chief of the many research papers and books produced by Don and the team. Don received a BA (1941) and a MA (1943) in chemistry and chemical engineering and enrolled in Harvard Medical School, where he received his MD in 1946. He completed an internship, a year of hematology training, two years in the Army, a year of postdoctoral research at MIT, and two years of medical residency at the Peter Bent Brigham Hospital in Boston.

Don developed his interest in bone marrow and leukemia during medical school. Inspired by the successes of Sydney Farber with antifolate therapy for acute lymphoblastic leukemia, he initially studied marrow-stimulating factors under John Loofborrow, then later in his own laboratory. However, he was also intrigued by the studies of Jacobson and Lorenz, who demonstrated that shielding of the spleen or marrow infusion could protect a mouse against lethal irradiation, and those of Main and Prehn, who showed that a mouse protected from lethal irradiation by marrow infusion would acquire tolerance to a skin graft from the donor. Based on those and other studies, it became clear that radiation protection by marrow infusion relied on the transplantation of cells and not growth factors, and Don set out to develop bone marrow transplantation (BMT) as a therapy for

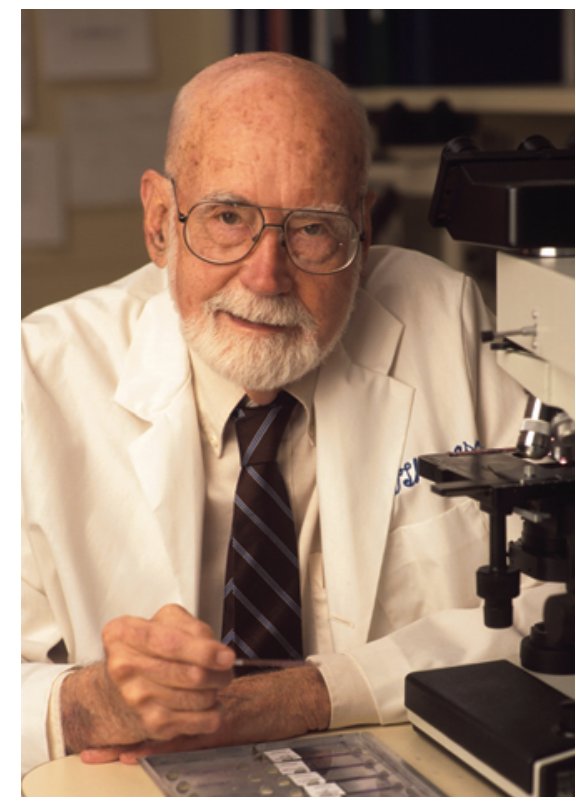

\section{Figure 1}

Photo credit: Suzie Fitzhugh.

patients with malignancies or congenital or acquired bone marrow failure.

In 1955, he was recruited by Joseph Ferrebee to be chief of the Mary Imogene Bassett Hospital in Cooperstown, and it was there that he began his BMT studies in an outbred large animal (dog) and his first clinical attempts to perform BMT in patients. By 1957, the first six patients had died within 100 days, the sole survivor a patient with leukemia who received a marrow infusion from his twin sibling. That patient survived the transplant, but unfortunately later died from a relapse of his malignancy. In his Nobel lecture, Don described the intense focus of those years: "The long cold winters, absence of commuting problems and opportunity for long discussions were conducive to our work. Those years had a deep and abiding influence on subsequent work since most of the basic concepts were laid out during that time."

In 1963, Don was recruited by Robert Williams to the University of Washington, Seattle, and relocated his research program to the United States Public Health Service Hospital in Seattle. His BMT program was one of the few of its kind; the technique was so unknown that Rainer Storb, who joined his group in 1965, recalled that the univer- sity print shop provided them with letterhead reading "Division of Hematology and Transportation.” Patients received their radiation in an underground World War II bunker. Don and his team immunized horses to obtain antiserum to inhibit rejection and graft-versus-host disease, a technique complicated by escaping and kicking horses. The initial progress was slow, and excepting those with twin donors, none of the first 54 bone marrow graft recipients survived, due to rejection, infection, graftversus-host disease, or malignant relapse. In response to these failed efforts, many colleagues declared the pursuit of BMT between individuals a lost cause. However, Don persisted when others abandoned the field, and, using the emerging knowledge of the human histocompatibility system as well as a better understanding of clinical complications and care, he performed the first BMT for a leukemia patient in March 1968 and the first BMT using a matched unrelated donor in 1979.

In 1975 , he moved his program to the new Fred Hutchinson Cancer Research Center, where it further developed into one of the most prominent programs in the world. Don remained head of the Seattle transplant program, Director of Clinical Research for the Hutchinson Center, and head of the Division of Medical Oncology for the University of Washington through his retirement in 1989. In addition, he served as the first Chief of Medical Oncology and later as its Director of Clinical Research.

In 1990, Don shared the Nobel Prize in Physiology or Medicine with Joseph Murray, who performed the first successful kidney transplantation. Throughout his career, he received many other awards, including membership of the National Academy of Sciences (1982) and the National Medal of Science (1990).

Don was a visionary and true pioneer who led the development of BMT from the laboratory to the bedside against all odds. His legacy is enormous: BMT is now an accepted and potentially life-saving therapy for many patients - in 2010, the one millionth patient received a BMT. Just within the United States, more than 120 centers perform BMT, and more than 15 million volunteer donors worldwide are registered. Many transplant programs around the 
world were started by his trainees. Apart from his enduring legacy in BMT, his work has also paved the way for the clinical translation of other emerging stem cell therapies. The effects of Don's accomplishments have been profound, and his dream lives on and is more relevant than ever.

\section{Marcel R.M. van den Brink}

Memorial Sloan-Kettering Cancer Center, Department of Immunology and Medicine, Mailbox 111, 1275 York Ave., New York, New York 10021, USA. Phone: 646.888.2304; Fax: 917.432.2375; E-mail: vandenbm@mskcc.org.

\section{John A. Hansen}

Department of Medical Oncology, University of Washington, Fred Hutchinson Cancer Research Center, 1100 Fairview Avenue, North D2-100, Seattle, Washington 981091024, USA. Phone: 206.667.5111; Fax: 206.667.5255; E-mail: jhansen@fhcrc.org. 